\title{
EDUCADORES FÍsICOS DO CONSUMO?
}

PHYSICAL EDUCATORS

OF THE CONSUMPTION?

\section{AUTOR}

Alessandro Barreta Garcia

Universidade Nove de Julho

EDUCADORES FísICOS

DO CONSUMO?

4(2): 89-93

\section{PALAVRAS-CHAVE}

educação física; estética;

fetiche; consumo.

\section{KEYWORDS}

physical education; aesthetic; fetish; consumption.

\section{RESUMO}

Este ensaio tem como objetivo, apresentar a estética com mercado de consumo, e demonstrar aos acadêmicos do curso de Educação Física a problemática do fetiche (busca do corpo como mercadoria na sociedade capitalista), bem como as implicações negativas desta ideologia consumista.

\section{ABSTRACT}

This assay has as objective, to present the aesthetic one with consumption market, and to demonstrate to the academics of the course of Physical Education the problematic one of fetiche (it searchs of the body as merchandise in the capitalist society], as well as the negative implications of this consumista ideology. 


\section{INTRODUĈ̣̃O}

\section{A mercadoria}

Sabe-se que o processo de mercantilização dos séculos XVII e XVIII apresenta-se através da teoria de Marx (1983), que entende a mercadoria como um objeto externo, na qual tem por extensão satisfazer as necessidades dos seres humanos. 0 que nos remete a simplificar a mercadoria a partir de bens primários e secundários. Marshall (1982) neste caso diferencia duas formas de mercadorias: a) gastos com alimentação, vestimenta, habitação, ou seja, consumo básico de sobrevivência; b] a excessos do consumo, extravagância, ostentação e satisfação dos sentidos na busca de prazer.

Marx (1983) classificará esta mercadoria prazerosa como um fetiche das satisfações, e responderá que este caráter de fetiche será proveniente da relação do trabalho despendido e grau de valor estabelecido. Assume-se aqui um papel puramente Metafísico ou socialmente fantasmagórico, figuras mentais que para Marx (1983) se revelam autônomas e mantenedoras de relação com os homens. Segundo Marx, "só satisfazem as múltiplas necessidades de seus próprios produtores" (Marx, 1983, p. 72). Além disso "O produto satisfaz hoje a uma necessidade social. Amanhã será, talvez, deslocado parcial ou totalmente, de seu lugar, por uma espécie semelhante de produto" (Marx, 1983, p. 95).

Quando nos remetemos ao contexto do corpo e da estética da Idade Moderna, Carvalho (1995) demonstrará a extensão do problema do consumo da atividade física lou como seu entendimento, o mito da atividade física e saúde] como produto da Idade Moderna. Neste mesmo contexto Morin (1969) destacará como cultura de massa e a erotização do Mercado Moderno. Comprando-se a beleza, a estética e o brilho artificial. É o corpo como mercadoria na Sociedade Capitalista.

Dada esta exposição assumimos agora a responsabilidade de transformar esta mercadoria entendida com extravagância e consumo desenfreado a partir da suposição do corpo como mercadoria em si próprio. Deslocaremos o entendimento de Marx (1983) para o entendimento da mercadoria como fator interno, ou seja, a busca do estético do corpo belo em si mesmo. Mas onde queremos chegar? Queremos dizer que na realidade o homem não busca somente a estética em produtos externos (na mercadoria externa), mas busca o estético nele mesmo. Sendo assim, ele vai a uma academia de ginástica para ter músculos fortes (esta é a reprodução da estética nela mesma), compra suplementos alimentares para aumentar a massa muscular (o estético nele mesmo], e melhor seria classificado como o homem na busca de sua própria modificação, ele é a sua matéria prima e é ele mesmo um produto em si.

Esta busca em si nada mais é que a estética do corpo como um fetiche que segundo Quadros (1976) é um utensílio cultivado como ídolo, objeto de adoração, sobrecomum ou cega dedicação. Seria o amar somente em parte, o amar de forma estratificada. Segundo esta definição o homem cultiva seu corpo e o transforma em mercadoria ou como chamaremos, de fetiche do corpo na Modernidade. $\mathbf{O}$ belo das atitudes, das virtudes, agora é o belo da forma, da imagem e do consumo do corpo belo, perfeito e oco.

\section{O corpo como Mercadoria}

Para respondermos ao nosso objetivo no qual tem por finalidade demonstrar que o corpo acadêmico da Educação Física (os Bacharéis) contribui para este mercado de consumo e do fetiche da estética, recorreremos não só ao fato de este consumo estar arraigado na mídia exploradora do assunto, mas de fato no que se refere ao corpo acadêmico que tem se direcionado para esse consumo. Mas este mercado de consumo Moderno e também proveniente de um aspecto comercial de nossa própria área, e alguns dos títulos são conhecidos como; "musculação estética \& wellness", "técnicas no tratamento da estética corporal", "estética corporal e facial", "mulher, exercício e saúde", "mulher, exercício e saúde", "Clínica de musculação personalizada", "Polestar Pilates": "Saúde e bem estar" "Musculação em Academia", "Corrida Qualidade de Vida, Estética e Performance", "Método Pilates", "Personal Training Direcionado a mulheres em busca da estética..." "personal trainer" visando saúde emagrecimento e qualidade de vida (270 ENAF, 1999; 140 FITNESS BRASIL INTERNACIONAL, 2004; 36o ENAF, 2004; 37o ENAF, 2004; 380 ENAF: Educação Física, 2005; 19a JOPEF, 2005) associando-se muitas vezes ao bem estar, no caso do termo wellness.

Sendo um mercado tão promissor que a própria indústria fitness; IHRSA (International Health, Racquet \& Sportsclub Association] tratou de apoiar para governador [do Estado da Califórnia - EUA] o consagrado ator e fisiculturista do passado; Arnold Schwarzenegger (FITNESS BUSINESS, 2003).

\section{O Fetichismo da Educação Física}

O profissional de Educação Física [em especial o Bacharel], tem se 
posicionado mesmo que inconscientemente a favor de um corpo como mercadoria. Este profissional no que tange nosso conhecimento, tem demonstrado uma certa intimidade com o que poderíamos chamar de alienação do corpo em um mercado extremamente consumista. $\mathbf{O}$ homem é alienado por um mercado consumista, e não percebeu que sua alienação o transformou em um produto que se coloca necessário. Mas será necessário? Como se não bastasse a alienação pelo lazer (Aranha \& Martins, 2002), o homem agora se encontra alienado por uma busca desenfreada por ele mesmo, é a sua própria adoração, é o fetiche que o homem tem pela sua própria imagem, a imagem que lhe é imposta. Mas em que esta adoração implica? Esta adoração implica em uma busca do belo e das formas em detrimento do belo da alma. Como se o mundo somente fosse inteligível, visivel a partir do que se expressa através da estética de uma forma bonita. Mas o que mais o homem tem de bom laos professores ou estudantes de Educação Física) além de suas formas não disponíveis a todos, mas tão somente a quem pode comprá-las? Ou mesmo a quem não as pode comprar, "mas sonham com elas"? 0 que os Educadores Físicos estão fazendo? Em que estão contribuindo, além de proporcionarem aos homens, a terem sonhos, às vezes impossiveis, ou provavelmente possíveis quando expressos em ilusões, "mesmo que de forma artificial"? Qual é o cuidado que se tem quando lidam com sonhos, fantasias, felicidade, adoração e desejos? Ou com a própria saúde? Qual é nossa responsabilidade neste mundo econômico e não menos social?

Que tipo de educadores somos? Ou queremos ser?
É preciso repensar, quais caminhos vamos seguir. Como diz Morin. "Há, no Homem que parece dever esconder-se como um eremita, sob os estranhos objetos de sua propriedade, a cega aspiração à comunicação com o outro" (Morin, 1969, p. 191). 0 homem quer falar, se rebelar, se transformar. É o prenúncio de uma mutação social, um distanciamento da técnica e do produto. Este Homem pede por socorro, pede por ajuda, e quer solução.

\section{CONSIDERAC̄ÕES}

Entendemos que o corpo é a própria mercadoria, é um tipo de consumo, passando-se de matéria prima para um produto final, pertencente ao mundo da fantasia, dos desejos, e do modelo ideal de um corpo perfeito. Mas o problema maior é encontrar na própria Educação Física [aos Bacharéis] o alimento aos sonhos de um consumidor seduzido. $\mathbf{O}$ problema estará na formação? Talvez sim, pois se temos filhos rebeldes é porque nossa Educação contribuiu de alguma forma. Se tivermos Educadores Físicos preocupados com a proliferação apenas de um corpo belo, de alguma forma a formação superior lhe proporcionou este resultado.

Acreditamos que em parte a responsabilidade recai sobre o corpo acadêmico, e por outro no corpo discente que não se vê apto a criticar. Mas em fim parte do problema é da Educação Física. Esta que trata da relação do homem com as práticas corporais, é nela que necessariamente se deveria compor a formação, humanização e a socialização do homem frente à diversidade de uma cultura corporal.

\section{REFERÊNCIAS}

1. Aranha MLA, Martins, MHP. Filosofando: Introdução à filosofia. São Paulo, Editora Moderna LTDA, 2002, 395p.

2. Aristóteles. A política. São Paulo, Martins Fontes , 2002, 321p.

3. Carvalho YM. O "mito" da atividade física e saúde. São Paulo, Editora Hucitec, 1995, p. 133.

4. Chauí M. Convite à Filosofia. $12^{\text {a }}$ Edição; São Paulo, Editora Ática. 2002, 440p.

5. Kohan WO. Infância e educação em Platão. Educação e Pesquisa, São Paulo, 29(01), pp. 11-26, Jan/ /Jun, 2003.

6. Lafargue P. $\mathbf{O}$ direito a preguiça. Tradução [de] Massano, A. J. 3 a Edição, Lisboa, Editora Teorema, sem data, 73p.

7. Luckesi CC, Passos, ES. Introdução à filosofia: aprendendo a pensar. $4^{a}$ Ed. - Editora São Paulo, Cortez - 2002, 271p.

8. Mannion J. 0 livro completo da Filosofia.: entenda os conceitos básicos dos grandes pensadores: de Sócrates a Sartre. Tradução (de) Fernanda Monteiro dos Santos. São Paulo: Madras, 2004, 286p.

9. Marshall A. Princípios de economia: tratado introdutório. Tradução (de) Rômulo de Almeida \& Ottolmy Strauch São Paulo, Abril Cultural, 1982, 272p.

10. Marx, K. O Capital: critica da economia política. Tradução (de) Regis Barbosa e Flávio R. Kothe. São Paulo, Abril Cultural, 1983, $301 \mathrm{p}$.

11. Mattiuzzi AA. Mitologia ao alcance de todos - deuses da Grécia e Roma antigas. Editora Nova Alexandria, São Paulo, 2000, 184p.

12. Morin E. Cultura de massas no século XX: $O$ espírito do tempo. 
Companhia Editora Forense, Rio de Janeiro - São Paulo, Tradução (de) Sardinha MR.

13. Platão. Diálogos. Tradução [de] Jose Cavalcante de Souza, Jorge Paleikatne e João Cruz Costa, $2^{\text {a }}$ Edição, - São Paulo: Abril Cultural, 1979, 261p.

14. Pope Junior HG, Phillips KA, Olivardia R. O complexo de Adônis: A obsessão masculina pelo corpo. Tradução (de) Sérgio Teixeira, Rio de janeiro, Campus, 2000, 316p.

15. Quadros JS. Novo dicionário da língua portuguesa. São Paulo, Rideel, 1976, 1211p.

16. Schopenhauer A. O mundo como vontade e representação. III parte. pp. 3-82. In Schopenhauer A. Os Pensadores. Tradução de Marr WL, Oliveira Cacciola MLM. São Paulo: Editora Nova Cultural, 1988, 240p.

17. Verenguer RCG. Ginástica e Platão: que dupla é essa? Revista Paulista de Educação Física, São Paulo, 7(1), pp. 69-79, Jan/Junh, 1993.

\section{Outros documentos}

1. FITNESS BUSINESS. Informativo da Industria Fitness Latino-Americana. $\mathrm{n}$-10, Novembro/Dezembro de 2003.

2. 36o ENAF: Educação Física. Poços de Caudas, Ano IX no 16, Abril de 2004.

3. 37o ENAF: Educação Física. Poços de Caudas, Ano X no 20, Outubro de 2004.

4. 14a FITNESS BRASIL INTERNACIONAL. Santos, 28 de Abril a 2 de Maio de 2004.

5. 38o ENAF: Educação Física. Pocos de Caudas, Ano X nำ 21, Abril de 2005.

6. 19a JOPEF. Jornada Paranaense de Educação Física, Fisioterapia, Nutrição, Turismo e Hotelaria. Curitiba, Maio de 2005. 